\title{
Role Of Customary Institution In Conflict Resolution Of The Rights On Customary Communal Land (Study on communal land conflict in Simangambat Jae Village Simangambat district of Padang Lawas Utara Regency)
}

\author{
Mukhrizal Effendi', M. Arif Nasution'2, R. Hamdani Harahap", Muryanto Amin \\ Doctoral Program of Development Studies, Faculty of Social and Political Science, \\ University of North Sumatera \\ Email:muryantoamin@gmail.com
}

\begin{abstract}
Customary communal land's conflict between Hasibuan's tribe indigenous people and PT. Torganda is a dynamic conflict of customary communal land which occurred in Simangambat Jae village Simangambat District of Padang Lawas Regency for a long time. Many efforts have been done by the customary institution to resolve the problem, by having advocate advice from customary institution, Civil Society Organization (LSM) and legal aid institution (LBH) to request help from (parliament, Tapanuli Selatan Regency government office, and National Land Agency) until the legal fight. This study uses a Qualitative-Descriptive research method with case study approach, this study will systematically dig up the information of customary communal land conflict to find out the conflict dynamic of the comunal land and the resolution has been done. Theory concept used in portraying the comunal land conflict in Simangambat Jae Village in Simangambat Disctrict of Padang Lawas Regency is customary law, customary law community, costumary comunal land, customary functionary, conflict theory, and government role. Seen from the conflict occurred between the chief of customary, customary community and the plantation management and also the concession problem over comunal land where the government should involve in finding resolution to the conflict. There was a role of shadowed actor behind the main actor to create a new conflict as an effect of the unsolved main conflict. The dynamic of previous conflict form a horizontal conflict, and the complex of actors creates a friction of issue and form a vertical conflict. The conflict originally based on behalf economy, socio-cultural, politic and law of the whole actors of the chief customary, Hasibuan clan's indigenous people, and plantation management which threaten the identity (horizontal conflict), now become the Hasibuan clan's indigeneous people with government (Vertical conflict) in Simangambat Jae village Simangambat District of Padang Lawas Regency that counting the customary comunal land in register 40 which is a part of protected forest.
\end{abstract}

Keywords: conflict, customary communal land, indigenous people, customary institution

\section{INTRODUCTION}

Land for human's life contains a multidimensional meaning. First, from economic point land is a production tool which attracts prosperity. Second, in the politic land can determine one's position in society decision making. Third, as cultural capital can determine the land owner's level of social status. Fourth, the land is sacred since at the end of one's life will be back to land. Because of those multidimensional meaning, there is a tendency that someone who owns land will fight to preserve it at cost when his right is violated. ${ }^{1}$

Native will always face with development issue agenda-setting which not comes from the native's aspiration, like government or company interest. Usually, development agenda become a reason to force them to release their communal land's right and worse the got criminalized live forced out, house burning and even in prison for devastation charge. Which happened because they protest the government to preserve their heritage and life sustainability.

The uneven of development will always be the reason because of the dutch east indies colony's heritage. In which, colonialism is a child of capitalism, like feudalism basically is a way to do economy where the king, king's family, and nobles. Different with capitalism of production tool controlled by capital owners. The capital owner has the freedom that production tool can be owned by anyone. Means that colonial can not change the feudal government system but to preserve the system by giving power to king and regent to collect the yield asked by colonial such as to export and let the farmer live in the boundary of life (subsistence). ${ }^{2}$ 
North Sumatera, the majority of people is Batak tribe which embraces a patrilineal system that has communal land owning, it is important to maintain the shared group so that Bataknese people is difficult to break it's relation with land even when the area owned is less. Padang Lawas Utara regency still exists communal land which increases conflict and dispute.

Every year, conflict and a land dispute occurs in almost every district and handled by any litigation, that is through court and an alternative way to solve which through another medium out of court. Communal land conflict which happen in Simangambat Jae village Simangambat district of Padang Lawas Utara regency between Hasibuan Tribe's indigenous people, plantation management (investor) and central government, it happen because Hasibuan tribe people (Suku Batak) see and feel that the land in Luhat Simangambat is communal land inherited generation to generation (genealogic) by the ancestors to the people for traditional ceremony, farming, and animal breeding.

Simangambat Jae is a village located in Simangambat district, Padang Lawas Utara regency, North Sumatera Province, Indonesia. Simangambat Jae istrict is a unification of 20 village which now happen to be 34 villages after division in 2008, they are: huta pasir, mandasip, langkimat, huta baru, janji matogu, paran padang, jabi-jabi, gunung manaon sim, sionggoton, ulak tano, tanjung maria, ujung gading jae, huta baringin, labuhan jurung, gunung manaon $u b$, ujung batu julu, martujuan, paya bahung, ujung batu jae, tobing tinggi, marlaung, mananti, jambu tonang, manare tua, pasir lancat julu,huta raja anda kosik putih ${ }^{3}$.

The conflict of communal land in Luhat Simangambat happened since early 1874 in the period of Luhat Simangambat Sultanate led by a king named sultan Sample Dibata, the conflict occurred because Kota Pinang Sultanate and Siak Sultanate and Siak Sultanate harried the land of Luhat Simangambat. To finish the conflict of borders an agreement was made in 1929 to set the borders of Luhat placed in Siak Sultanate which poured in a map, Sultan Mahodum Hasibuan took place as representative of Luhat Simangambat accompanied by Patoan Bosar Hasibuan and dalian na tolu.

Based on Governor's decree number 785 in 1950 pointed Simangambat and ujung Batu to be an urban village as contitution policy no 27 in 1948.constitution no 12 year 1949 and government decree no.9 in 1950 Luhat Simangambat has 20 villages, they are simangambat jae, simangambat julu, Aek raru, Ujung Gading Jae, Ujung Gading Julu, Langkimat, Mandasip, hutapasir, hutabaru, paran padang, jabi-jabi, janji matogu, sigagan, gunung manaon, tanjung botung, si Onggotan, ulak tano, pagarantongga, Sibulang-bulang and Hutabaringin.

In 1986 by 20 chief villages together with indigenous people in Luhat Simangambat authorize King Panusunan Bulung ( the ancestry of Sultan Mahodum Hasibuan) to be appointed as the deputy of Communal land Luhat Simangambat to find investors to cultivate the communal land Luhat Simangambat as partners. Then in 1988 by King Panusunan Bulung altogether with Hatobangon / intellectuals/scholars and chiefs to register communal land to subdistrict head of Barumun Tengah and to register in the National land agency in Jakarta.

Meanwhile, one of the conflict triggers happened in Luhat Simangambat in 1997 was caused by the chief of Ujung Gading Jae village and chief Ujung grading Julia who sold the communal land for their own benefit without permission from people, the danger of Hasibuan tribe people to lose their communal land. To avoid it happen again, the chiefs and indigenous people in Luhat Simangambat sent the representative to find an investor to consultative the land and invite the president director of PT Torganda DL.Sitorus to promote the society of Luhat Simangambat which classified as Lessdeveloped village-inpres Desa Tertinggal (IDT). Coincidentally DL.Sitorus married a Hasibuan Woman lived in Toba (North Tapanuli). After a discussion or agreement between people of Luhat simangambat and D.L Sitorus continued with custom feast started with the people in Luhat Ujung Batu on August and December 1998 with people of Luhat simangambat at that time D.L Sitorus gave a half of pago-pago money. Before pago-pago money given an agreement made on a certificate. Part of communal land given to PT.Torganda was a neglected land, nonproductive and filled with weeds, even though in some spots planted with palm treesporadically and not maintained which was ex HPH PT. Rimba Baru width \pm 48.000 ha and HPH PT. Bakaraz Lumber co \pm 60.000 ha with total area \pm 108.000 ha. 
About \pm 36.000 ha of whole \pm 108.000 ha has been handed to Trikora Mandara Sumatera organization. And the rest \pm 72.000 Ha handed by people to DL.Sitorus as stated in the certificate. Where in the certificate stated the profit sharing with PIR pattern by comparison of $70 \%$ for society (plasma) and $30 \%$ for management (PT.Torganda) as a foster father. Based on the observation that in Luhat Simangambat and the surrounded area there were already oil palm plantations: PT. First Mujur Plantation, PT.Wonorejo, PT.Eka Pendawa Sakti which became PT.Austindo, PT.Barumun Rapala, PT. Mazuma Agro Indonesia, PT.AMKS, PT.Pondok Sindor, Ginting Group, PT.Kass, PT.Parombunan, PT Sumber Jaya Makmur, PT.Jerman, Rimnitahi Cooperative of Civil Servant and Serbaguna Cooperative of village unit.

From the previously explained plantations, there is non of them give a contribution to the society in PIR (Plasma Inti Rakyat) pattern, except Harapan Oil Palm plantation cooperative. Various form of concern to society, Harapan oil palm plantation cooperative built facilities and main road including public facilities and main road including public facilities as a mosque, church, school, Islamic boarding school, community health clinic, and traditional market.

Next conflict appeared in 2014 from the government who did embargo to the plantation side by accusing them not having any business entity and penetrated the protected forest which postscripted as registered area 40. On another hand, indigenous people Hasibuan as native working as farmer feeling aggrieved by the regulation to close the selling access of Crude Palm Oil (CPO) because they expected it as their source of income. And for the plantation side. Which got sanction from the government for their negligence in handling permits and be censured by the government since they blamed for cutting trees without forest management nights $(\mathrm{HPH})$ and controlling the forest.

Access to the land is the wish of some people in Simangambat Jae village Simangambat district Padang Lawas Utara regency, even though it was fought for a long time, hard to happen because of the policy by government to limit the access. Because of that, the key issue of this study is about how those people who claimed themselves as indigenous people fight together to get the access to the Communal land. Here, one of the main forum to fight the access is a customary institution. The customary institution in this study is an institution which interacts daily with society and plays an important role in distributing the land instead of other forums, such as BPN and local custom functionary. There are five villages which have this kind of conflict such as: Langkimat, Tanjung botong, mandasip, hutabaru, and hutapasir and also the role of custom functionary is still existed and accepted by people although there are some factors to affect the operation. The factors affecting int he process of custom functionary ensuring the access are : knowledge of customary law, social status, network owned by custom functionary and figures, information gathered by people, relationship between custom functionary and state institution, obedience of indigenous people, acts and behavior of migrants, the response of field bureaucrat, economic interest of each actors.

With that kind of understanding cause indigenous people of Hasibuan clan, especially people of Simangambat Jae village to think that the people who live and control the land location has taken their right of communal land or being less involved in the process of land acquisition, where it considered as the communal land of Hasibuan clan. This dissatisfaction forced indigenous people to demand the central government and plantation management to return and admit their rights of communal land. On the other hand, the communal land controlled by custom functionary has already owned and the government has given them land acquisition in person or business entity. Yet other people have no certificate to claim their land. Even though, those lands controlled and planted and processed by indigenous people of Hasibuan clan.

According to the previous analysis and background of the problem, the problem in this study is the role of the custom functionary in solving the conflict of communal land in Simangambat Jae village Simangambat district of Padang lawas utara regency into questions, they are :

1. How is the procedure and policy of custom functionary in conflict solving of communal land in Simangambat Jae village in Simangambat district of Padang lawas utara regency?

2. How is the conflict resolution of communal land appeared from indigenous people reaction which has got affected by the land acquisition? 
As for the aim of this study is to describe conflicts of communal land rights occurred between people in Simangambat Jae village in Simangambat district of Padang lawas utara regency and the government/concessioner, also plantation management. This result hopefully becomes a consideration to superintendant to increase the continuously forest clearing which lead to deforestation or forest conversion.

\section{METHOD}

\section{A. Research Design}

This research design is using case study method by the qualitative approach and descriptive research type. The reason is to get deeper, systematic, factual, and accurate description of facts and relation between the studied phenomenon. The informants in this research are indigenous people of Hasibuan clan, BPN in Padang Sidimpuan and also Forestry Service. While the data collecting service by interview was not structured with the related informant of communal conflict happened between two groups they are indigenous people of Hasibuan clan, Bukit Harapan KPKS and government. ${ }^{4}$

That, descriptive method with qualitative approach hopefully reveal the real condition that happens in Simangambat district and to open up the hidden phenomenon (hidden values) of all society dynamic. Because basically this study will describe and do the exploration in details about the research problem. Besides, descriptive research method which articulates the research result in descriptive data (orally or written and the observation from the observed people) will be more valuable and convince the policy maker rather than a discussion by using numbers.

\section{B. Location of Research}

The choice of research location based on motive and consideration such as the land owning and controlling under customary law and having communal land conflict, the location of the research are:
Table 1: Total area specified per subdistrict/village in Simangambat district in 2015 (The statistic of Simangambat District 2015)

\begin{tabular}{|l|l|l|}
\hline The name of village & $\begin{array}{l}\text { An Area } \\
\mathbf{( K m}^{2} \mathbf{~}\end{array}$ & $\begin{array}{l}\text { Percentage } \\
\mathbf{( \% )}\end{array}$ \\
\hline 1. Huta pasir & 28,98 & 4,15 \\
\hline 2. Mandasip & 8,45 & 1,21 \\
\hline 3. Langkimat & 26,28 & 3,76 \\
\hline 4. Hutabaru & 26,44 & 3,78 \\
\hline 5. Janji matogu & 24,55 & 3,51 \\
\hline 6. Paran padang & 3,30 & 0,47 \\
\hline 7. Jabi-jabi & 5,29 & 0,76 \\
\hline $\begin{array}{l}\text { 8. Gunung manaon } \\
\text { sim }\end{array}$ & 7,08 & 1,01 \\
\hline 9. Sionggotan & 18,98 & 2,72 \\
\hline 10. Tanjung botung & 5,16 & 0,74 \\
\hline 11. Aek raru & 5,73 & 0,82 \\
\hline $\begin{array}{l}\text { 12. Simangambat } \\
\text { julu }\end{array}$ & 19,36 & 2,77 \\
\hline 13. Sigagan & 24,43 & 3,49 \\
\hline 14. Simangambat jae & 25,54 & 3,65 \\
\hline 15. Pagaran togan & 28,18 & 4,03 \\
\hline 16. Ujung gading julu & 26,61 & 3,81 \\
\hline 17. Ulak tano & 28,88 & 4,13 \\
\hline 18. Tanjung maria & 25,53 & 3,65 \\
\hline 19. Ujung gading jae & 26,16 & 3,74 \\
\hline 20. Huta baringin & 4,49 & 0,64 \\
\hline 21. Labuhan jurung & 14,62 & 2,09 \\
\hline $\begin{array}{l}\text { 22. Gunung manaon } \\
\text { ub }\end{array}$ & 25,76 & 3,69 \\
\hline 23. Ujung batu julu & 24,69 & 3,53 \\
\hline 24. Martujuan & 3,85 & 0,55 \\
\hline 25. Paya bahung & 26,02 & 3,72 \\
\hline 26. Ujung batu jae & 25,31 & 3,62 \\
\hline 27. Tobing tinggi & 4,23 & 0,61 \\
\hline 28. Marlaung & 24,78 & 3,54 \\
\hline 29. Mananti & 25,10 & 3,59 \\
\hline 30. Jambu tonang & 26,25 & 3,76 \\
\hline 31. Manare tua & 27,78 & 3,97 \\
\hline 32. Pasir lancat julu & 23,77 & 3,40 \\
\hline 33. Huta raja & 17,46 & 2,50 \\
\hline 34. Kosik putih & 60,00 & 8,58 \\
\hline AMOUNT & $\mathbf{6 9 9 , 0 4}$ & $\mathbf{1 0 0 , 0 0}$ \\
\hline
\end{tabular}

\section{INFORMANT AND DATA COLLECTION}

Research method using a case study with several data collection, such as: observation, library research, in-depth interview, and key informant. Key informant involves 10 persons whom purposively selected they are directly 
involved in the communal land conflict in Simangambat Jae village in Simangambat district of Padang lawas utara regency :

1. Local government of Padang Lawas Utara regency

2. The regional representative council of Padang lawas utara regency

3. The chief of land registry office of Tapanuli Selatan

4. The chief of Forestry service of Tapanuli Selatan

5. Simangambat District office

6. The village heads

7. Farmers association (local SPI)

8. Legal aid institute (LBH)

9. Public figures/ Religious figures/custom

10. Indigenous people

And the data collection in this study done by being a focus on the informant and the researcher point of view who acted as a key informant and directly involved in collecting data deeply. This suitable for the opinion from Bogdan and Biklen (1992) that: "Qualitative research has the natural setting as the source of data and researcher is a key instrument."

\section{RESULT AND DISCUSSION}

A. Conflict between the chief and indigenous people (Horizontal conflict)

Teer Haar Bzn on his book titled: "Beginzelen en stencil van het Utrecht", stated that the applied custom law in the society can be a binding law of behavior in every appointment of the chief. Thus, the chief through customary institution act as the ruler of custom law. The conflict resolving procedure of communal land in a customary society has not developed in concrete as well as the mechanism of land rights proposal, conflict resolving is not conducted in an even way, but by experience and customs of local society. 5

The result of an interview with customary figure and indigenous people was that the communal land may be sold under some requirements of customary law and approved by the people. Yet, what happened in Luhat Simangambat the communal $\mathrm{l}$ and was traded by the village chiefs, without consent from and compensation to the people for their own advantages. The communal land used as a source of life, but it sold to anyone who has got money. The trading process of communal land is unlimited based on demand.
Customary law/ habitual of indigenous people Hasibuan clan in Simangambat, they have sanction to the chief whenever they did manipulation or power misappropriation or in other words sold the communal land to the outer people without consent from and compensation to the people, thus the sanction given to the law breaker was to be isolated from village or sent out from village. To prevent this occurred again, then the customary protect the people by becoming a mediator to reach deliberation between plantation management and indigenous people by hosting a custom feast and invite indigenous people and handed "Pago-pago'. But before pago-pago was handed, there was an agreement on the notarial deed and arrange the share profit sharing Plasma Inti Rakyat (PIR) with comparison $70 \%$ for people of Hasibuan clan and $30 \%$ for plantation management (investor).

B. Conflict between indigenous people and plantation management (Horizontal conflict)

As administration area the plantation location managed by PT.Torganda called Luhat Simangambat by Hasibuan clan people located at the northern most Tapanuli Selatan which after area proliferation became Padang lawas utara regency directly bordered with the area of Kotapinang sultanate which now called Labuhan batu selatan regency, and on the north bordered with Siak sultanate of Riau province, on the west bordered with Padang bolak district.

The communal land handed by Luhat simangambat people to PT.Torganda was an abandoned before, un-productive and fulled by weeds, even though some area sporadically planted by unkempt palm trees about \pm 72.000 $\mathrm{Ha}$, poured in an agreement about the profit sharing in PIR pattern with comparison $70 \%$ for people (Plasma) and $30 \%$ for plantation management (investor) as a foster father. Then came Luhat heuristic on 2002 where the amount of family who was going to get plasma area are \pm 3000 heads of family ( $\pm 6000 \mathrm{Ha}$ ) and next Luhat Sosa people will get plasma area about \pm 22000 heads of family $( \pm 44.000 \mathrm{Ha})$, then by that the people became the member of cooperation Persadaan Simangambat Ujung Batu (PARSUB). Besides that on 1977 indigenous people of Huta Pasir village, Simangambat Julu and Aek Raru willingly given their empty land ( an area which has not done by people around the village \pm 1.000 
Ha) to government, Forestry service of Padang Sidimpuan regency.

Considering that the communal land which has given to and managed by KPKS Bukit Harapan for palm tree was consistent as the agreement, where the PIR member not yet have any clear status of their land so they conducted a demonstration to government and Tapanuli selatan parliament, as a response of demonstration by PIR member the government and parliament (commission A) of Tapanuli selatan, chief of customary, district government, head of village Hatobangon, the office of National land authority of Tapanuli selatan checked and rechecked that the land given by KPKS Bukit Harapan has already planted by palm trees and was fruitful. At the time an agreement was made that land questioned by PIR member could be processed to get a clear status of land owning. After an agreement on the field made then commission A of Tapanuli Selatan parliament invited KPKS Bukit Harapan, and as the result, KPKS Bukit Harapan was willing to give the palm tree-planted land to PIR members. In accordance to that, people proposed for a certificate of plasma land managed by KPKS Bukit Harapan as small enterprise partner. Following the people's request, the National land authority of Tapanuli Selatan asked for the status of register 40 boundaries to Forestry service of North Sumatera province and asked for directions.

The result of discussion with customary figures and people about the requirements to get permission to open forest was an agreement between company and people by giving some money (pago-pago) from company to people. Unfortunately, not all people got the advantage of this communal land acquisition. Only selected persons got the advantage especially those who have got relation with the plantation management. The other reason was seized land by people who did not get any profit from the land so that they tried to seizure the land and planted with palm trees and rubber. If the plantation management wishes to get back the planted land, then they must pay compensation as much as the land price or they must let go the land to be owned by indigenous people.

C. Conflict between indigenous people, plantation management, and government (Vertical conflict)

An argument between Forestry service and people about communal land located in the protected forest (Register area 40), which arouse the conflict between indigenous people and plantation management, BPN Tapanuli Selatan regency suggested that the indigenous people should immediately propose for land certificate application for plasma land which managed by KPKS Bukit Harapan as a partner. As a follow up to people's proposal, the National land authority of Tapanuli Selatan regency sent an official letter to Forestry service of North Sumatera province about the status of register 40 boundaries (Forest area of Padang laws).

Since the land status in Tapanuli Selatan regency been questioned by the National land authority (BPN) of Tapanuli Selatan regency through letter No.590.207/2/1989 dated February $10^{\text {th }} 1989$, the letter published and stated that:

a. Land owning status/land tenure in Tapanuli Selatan regency is: 1) land owned by indigenous people will continue from generation to generation, 2) communal land, and 3) land owned by the government.

b. Next stated that communal land status in Tapanuli Selatan regency existed and approved as ruled in article 3 and 5 of UU No.5/1960 about the basic agration regulations.

Ironic, that in 1977 the indigenous people of Huta Pasir Village, Simangambat Julu, and Aek Raru voluntarily handed over the empty land ( land which not planted) $\pm 1000 \mathrm{Ha}$ to the government. Forestry service of Tapanuli Selatan regency based in Padang Lawas district, which now after division to be Padang Lawas regency, planted by forestry plants. It showed that the area was communal land approved by the government, forestry service.

\section{CONCLUSIONS AND RECOMMENDATIONS}

\section{A. Conclusions}

Based on the research conducted by indepth interview method, key informant, and researcher as a key instrument, then it can be concluded that

- Reasons which became the background of communal land the conflict-affected by economy factor and social jealousy, because those lands sold by heads of the village without any consent and compensation to Hasibuan Clan people. Which, at that time people of Hasibuan clan actually wished for a better life and 
along with the rising price of land caused by development.

- Communal land conflict solving process in Simangambat Jae Village Simangambat district Padang Lawas Utara regency done out of law (non-litigation), by the forum to reach an agreement for people's demands to plantation management.

- The equality of perception between Hasibuan clan people with the government as concessioner of the existence and status of customary law by giving counseling in the land especially communal land.

\section{B. Recommendations}

As the end of discussion in this research, then researcher try to give suggestion which likely giving advantage for all party;

- The government of Padang Lawas Utara regency needs to make an earth map about position, range, and borders of communal land in Padang Lawas Utara regency, so that at the end of the day there will be no more problem/conflict about communal land.

- The government of Padang Lawas Utara regency needs to be resolved, so every demand of from people about the land given without consent, done through litigation to give a clear law status to those who have got a land certificate as an official proof.

- The socialization of agreement reached from forum between indigenous people, plantation management, and the government is needed, so there will not be any partial claim about the communal land object, because until now there are some similar demands arouse on behalf of Hasibuan clan people.

\section{ACKNOWLEDGEMENT}

The writer is thankful to the Faculty of social and political science of North Sumatera University for giving chance to present this paper on the $2^{\text {nd }}$ International Conference On Social and Political Development (ICOSOP) as one of the requirements to finish the Doctoral Program of Development Study in The Faculty of Social and Political Science of North Sumatera University.

\section{REFERENCES}

[1] BPS., Statistik Daerah Kecamatan Simangambat 2016

[2] Bogdan, R. C., Biklen, S. K., 1992, "Qualitative Research for Education: an Introduction to Theory and Methods", Boston: Allyn \& Bacon. pp.

[3] Effendy, Irwan., "Penguasaan Tanah Adat Luhat Simangambat Kecamatan Padang Lawas Kabupaten Tapanuli Selatan dan Proses Sertifikat Tanah", Padang Sidimpuan: BPN TAPSEL, 2006, hal 1-15.

[4] Nasir, Mohd., "Metode Penelitian", Jakarta: Ghalia Indonesia, 2011, hal 5.

[5] Nugroho, Heru., "Menggugat Kekuasaan Negara", Surakarta: Muhammadiyah University Press, 2001, hal 237.

[6] Fauzi, Noer., "Petani dan Penguasa: Dinamika Perjalanan Politik Agraria di Indonesia", Cetakan I, Yogyakarta: Pustaka Pelajar, 1999, hal 15-16.

[7] Prodjodikoro, Wirjono., "Pengantar dan AsasAsas Hukum Adat", Mas Haji Agung: Jakarta, hal

161. 